\title{
Kardiyovasküler Sistem Hastalıklarının Risk Faktörleri Üzerine Beslenme Durumunun Etkisi*
}

\author{
The Effect of Nutritional Status on Risk Factors of Cardiovascular System Diseases*
}

\section{Melike DEMIR DOĞAN ${ }^{1}$ (D), Fatma TAYHAN KARTAL ${ }^{2}$}

ÖZ

Amaç: Bu çalışma besin tüketim sıklıklarının kardiyovasküler sistem hastalıklarının risk faktörlerini nasıl etkilediğini belirlemek amacıyla yapılmıştır.

Gereç ve Yöntem: Kesitsel bir araştırma olarak planlanan bu çalışma Gümüşhane Devlet Hastanesinde, kardiyovasküler hastalı̆̆ı olan bireyler arasından gönüllü olan 62 hasta ile yapılmıştır. Hastaların antropometrik ölçümleri araştırmacı tarafından uygun yöntemlerle alınmıştır. Verilerin değerlendirilmesinde Pearson Korelasyon Analizi kullanılmıştır.

Bulgular: Fast food ( $\mathrm{r}=0,260, \mathrm{p}=0,041)$ ve kek, kurabiye, şekerleme tüketimi sıklığ 1 ile LDL-kolesterol düzeyi ( $\mathrm{r}=0,252$, $\mathrm{p}=0,048)$ arasında, bireylerin kırmızı et $(\mathrm{r}=0,254, \mathrm{p}=0,046)$ ve süt ve süt ürünleri tüketim sıklığıyla beden kütle indeksleri $(\mathrm{r}=0,326$, $\mathrm{p}=0,006$ ) arasında pozitif bir ilişki bulunmuştur. Ayrıca süt ve süt ürünleri ile yumurta tüketim sıklığı arttıkça bireylerin HDLkolesterol değerleri de artmıştır (sırasıyla $\mathrm{r}=0,343, \mathrm{p}=0,010$ ve $\mathrm{r}=0,262, \mathrm{p}=0,039)$. Yine benzer olarak bireylerin çay/kahve tüketim sıklığındaki artış HDL-kolesterol düzeyini arttırmıştır $(\mathrm{r}=0,309, \mathrm{p}=0,015)$. Bunun dışında hamur tatlıları, simit, poğaça vb. tüketim sıklığıyla bireylerin trigliserit düzeyleri arasında, ayrıca sebze ve meyve tüketim sıklığı ile bireylerin bel çevresi arasında negatif yönde anlamlı bir ilişki olduğu bulunmuştur.

Sonuç: Sonuç olarak hamur tatlıları, şekerleme, fast food ve hamur işleri tüketimi kardiyovasküler hastalık risk faktörlerini olumsuz yönde etkilerken, süt ve süt ürünleri, kahve/çay ile yumurta tüketimi HDL kolesterolü arttırarak kardiyovasküler hastalıklar üzerinde olumlu yönde bir etkiye sahiptir.

Anahtar Kelimeler: Antropometrik Ölçümler, Beslenme, Kardiyovasküler Hastalık Riski

*Bu çalışma '3. Uluslararası Sağlık Bilimleri Kongresinde’ sözlü bildir olarak sunulmuştur

Melike DEMİR DOĞAN

${ }^{1}$ Gümüşhane Üniversitesi Sağllk Bilimleri Fakültesi, İç Hastallkları

Hemşireliği Anabilim Dall, Gümüşhane, Türkiye

Fatma TAYHAN KARTAL (四)

${ }^{2}$ Gümüşhane Üniversitesi Sağllk Bilimleri Fakültesi, Beslenme ve Diyetetik Anabilim Dal,, Gümüşhane, Türkiye

e-posta:fatma_tayhan@hotmail.com

\section{ABSTRACT}

Aim: This study was conducted to determine the consumption frequencies of food how affect the risk factors of cardiovascular system patients.

Materials and Methods: This study, which was planned as a cross-sectional study, was performed with 62 patients who were voluntary among the patients with cardiovascular disease in Gümüşhane State Hospital. The anthropometric measurements of the patients were taken by the researcher with the appropriate methods. Pearson Correlation Analysis was used to evaluate the data.

Findings: There was a positive relationship between fast food $(r=0,260, p=0,041)$ and cakes, cookies, sweets consumption frequency with LDL-cholesterol levels $(r=0,252, p=0,048)$ and between the red meat $(r=0,254, p=0,046)$ and milk and dairy products consumption frequency with body mass indexes $(\mathrm{r}=0,326$, $\mathrm{p}=0,006)$. Also, HDL-cholesterol values of individuals increased as milk and dairy products and egg consumption frequency increased $(r=0,343, p=0,010$ and $r=0,262, p=0,039$, respectively). Similarly, the increase in the frequency of tea/coffee consumption of individuals increased the HDL-cholesterol level $(\mathrm{r}=0,309$, $\mathrm{p}=0,015$ ). In addition to this, it was found that there was a negative correlation between the frequency of desserts, bagels and pastry etc. consumption among the triglyceride levels of individuals as well as between the frequency of consumption of vegetables and fruits with the waist circumference of individuals.

Conclusion: Consequently, while, the consumption of desserts, sweets, fast food and pastries negatively affect the risk factors of cardiovascular disease, the consumption of milk and dairy products, coffee/tea, egg have a positive effect on cardiovascular diseases by increasing HDL-cholesterol.

Keywords: Anthropometric Measurements, Nutrition, Risk of Cardiovascular Disease

\section{GíRiş}

Kalp hastalıkları dünya genelinde ölümlerin önde gelen nedenidir ve yılda 17 milyondan fazla ölüme neden olmaktadır. Bu da tüm ölümlerin \%31'ini oluşturmaktadır (1). Benzer şekilde ülkemizde de kalp hastalıkları \%40 görülme oranıyla 
tüm ölümler içinde ilk sıradadır. Ülkemizde 2011 yılı Türkiye Kronik Hastalıklar ve Risk Faktörleri Sıklığı Çalışması (TKrHRF) verilerine göre erkeklerde kardiyovasküler hastalık sıklığı \%3,8, kadınlarda \%2,3 olarak bulunmuş olmasına rağmen, 75 yaş üstü bireylerde bu oran erkeklerde \%19,6’ya, kadınlarda \%10,8'e kadar çıkmıştır (2). Kalp ve damar sistemi hastalıkları risk faktörleri arasında kan lipid profili bozuklukları, özellikle yüksek serum LDL-kolesterol ve düşük HDL düzeyi, hipertansiyon, sigara, obezite, diyabet, erkek cinsiyeti ve fiziksel inaktivite sayılabilir. $\mathrm{Bu}$ risk faktörlerinden biri olan obezite, kardiyovasküler hastalık risk göstergeleriyle de yakından ilişkilidir (3). Obez bireyler yağ dokusundaki artı̧s ve işlev bozukluğunun bir sonucu olarak kardiyovasküler hastalık gelişmesi açısından artmış bir riske sahiptirler. Özellikle organların çevresini saran visseral yağ dokusundaki artış, kardiyovasküler morbidite ve mortalite için bağımsız bir risk faktörüdür (4). Adipozite ile kardiyovasküler hastalıklar arsındaki bu ilişki, yüksek BKI (beden kütle indeksi)'nin yüksek trigliserit ve LDL-kolesterol seviyeleri ve düşük HDL-kolesterol seviyelerini içeren dislipidemi riskindeki artış ile açıklanabilir. Dislipidemi ile birlikte kronik inflamasyon, endotel disfonksiyona ve makrovasküler değişikliklere katkıda bulunarak, kardiyovasküler hastalıkların gelişmesine yol açar (5).

Diyet, düzenli egzersiz ve sigara kullanımının engellenmesi ile birlikte, dünya çapında mortaliteye katkıda bulunan kardiyovasküler hastalıkların gelişiminde ve önlenmesinde önemli bir rol oynamaktadır (6). Pek çok çalışmada hayvansal protein yönünden zengin aynı zamanda yüksek miktarda kırmızı ve işlenmiş et, rafine tahıl, şekerleme ve tatlı alımı ile karakterize bir beslenme tarzı, kardiyovasküler hastalık mortalite riskinde artışla ilişkilendirilmiştir (6-8). Toplam enerji alımındaki artış, özellikle yüksek karbonhidrat alımı kardiyovasküler hastalık risk faktörlerindeki artışla bağlantılıdır. Diyette yüksek karbonhidrat alımı küçük yoğunluklu LDL partiküllerini etkilerken, doymuş yağ alımı öncelikle daha büyük LDL partiküllerini etkileyebilir (9).

Yüksek karbonhidratlı diyetin aksine sebze, tam tahıl, balık, 1lımlı alkol, baklagiller ve az miktarda et tüketimini içeren sağlıklı bir diyetin, total kolesterol, trigliserid, kan basınc1, insülin direnci ve inflamatuar sitokinler gibi bir dizi kardiyovasküler hastalık risk faktörlerini azaltmasıyla ilişkili olduğu bildirilmiştir (10). Orta Doğu ve Kuzey Afrika bölgesinde yaşayan yetişkinler arasında kardiyovasküler hastalık riskindeki artışın batı tarzı beslenme şekliyle ilişkili olduğu, bunun tersine Akdeniz diyet modeli ve DASH [(Dietary Approach to Stop Hypertension) (Hipertansiyonun Önlenmesi için Diyet Yaklaşımları)] diyeti modeli gibi sağlıklı beslenme şeklinin kardiyovasküler hastalık risk faktörlerindeki azalmayla ilişkili olduğu bulunmuştur $(10,11)$. Böylelikle, sağlıklı beslenme, kardiyovasküler hastalıklar nedeniyle meydana gelen morbidite ve mortaliteyi önleyebilir, sağlık giderlerini azaltabilir ve yaşam kalitesini arttırabilir (12).

$\mathrm{Bu}$ çalışmanın amacı Gümüşhane Devlet Hastanesinde yatan, kardiyovasküler hastalık tanısı almış bireylerin beslenme alışkanlıklarını, bazı besinlere yönelik besin tüketim sıklıklarını araştırarak bunların kardiyovasküler hastalık risk faktörlerine ve antropometrik ölçümlere etkisini değerlendirmektir.

\section{YÖNTEM}

\section{Araştırma Tasarımı ve Örneklem}

Kesitsel bir araştırma olarak planlanan çalışma NisanHaziran 2017 tarihleri arasında Gümüşhane Devlet Hastanesinde yatan kardiyovasküler hastalığı olan gönüllü bireylerle yapılmıştır. Yapılan bu çalışmada örneklem sayısı yapılmış benzer çalışmalardan yararlanılarak güç analizi yöntemiyle belirlenmiştir. Bu çalışma 30 yaş üzerinde, android tip obeziteye ve yüksek serum trigliserit ve LDLkolesterol düzeylerine sahip birey sayısının fazla olması nedeniyle 30 yaş ve üzerindeki bireylerde yapılmıştır (13). 30 yaş üstü kardiyovasküler hastalık tanısı almış 62 birey rastgele örnekleme yöntemi kullanılarak seçilmiştir. 30 yaş altındaki, çalışmaya katılmayı kabul etmeyen bireyler, kanser, kronik karaciğer hastalığı teşhisi alan hastalar araştırma dışı bırakılmıştır.

\section{Veri toplama yöntemi}

Çalışmada veriler bireylerin genel beslenme alışkanlıklarını, kan parametrelerini ve genel özelliklerini içeren bir form kullanılarak, hastalarla veya hastada duyma, konuşmayla ilgili sorun olduğu durumlarda hasta yakınlarıyla yüz yüze görüşme tekniği ile yapılmıştır. Hastaların vücut ağırlığı Sinbo (SBS-4414) marka tartı ile boy uzunluğu baş Frankfurt düzlemde iken stadiometre ile ölçülmüsşür. Beden kütle indeks'leri (BKİ) hastaların vücut ağırlığının ( $\mathrm{kg}$ ) boy uzunluklarının $(\mathrm{cm})$ karesine oranıyla hesaplanmıştır (14).

Çalışmaya katılan hastaların yaş, cinsiyet, eğitim ve gelir durumu, meslek gibi sosyodemografik özelliklerini, 
kardiyovasküler hastalık dışında tanı aldıkları hastalıklar, tedavi alıp almadığı, kullanılan ilaçlar gibi sorularla genel sağlık durumu, anne, baba ve kardeşlerde kardiyovasküler hastalık, hipertansiyon, hiperlipidemi, diyabet ve kalp krizi gibi hastalıkların varlığı, sigara ve alkol kullanma durumu, günlük öğün sayısı ve su tüketimi, yemek yeme hızı, yemek pişirme yöntemleri, tüketilen yağ türü gibi genel beslenme alışkanlıklarını içeren bir form kullanılmıştır. Besin tüketim sıklıkları besin sıklık anketi kullanılarak değerlendirilmiştir (15). Çalışmaya katılan bireylerin vücut ağırlığı, boy uzunluğu, bel ve kalça çevresi gibi antropometrik ölçümleri alınmıştır. Bel çevresi ölçümü; birey ayakta iken, en alt kaburga kemiği ile kalça kemik çıkıntısı (iliyak) arasındaki uzunluk ölçülerek orta nokta bulunmuş ve ölçüm yapılarak belirlenmiştir. Kalça çevresi ise kişi ayakta iken yandan bakıldığında kalçanın en geniş çevresinden ölçüm yapılarak belirlenmiştir (14). HDL, LDL ve total kolesterol ve trigliserit düzeyleri hastane tarafindan yapılan biyokimyasal testlerle elde edilmiştir.

\section{Etik Değer}

Çalışmanın yapıldığı kurumlardan gerekli yazılı izinler alınmıştır. Çalışmaya katılmayı kabul eden tüm hastalara çalışma hakkında bilgi verilmiş ve sözlü onamları alınmıştır.

\section{Veri Analizi}

Verilerin analizi SPSS 22,0 programında yüzdelik, ortalama, korelasyon analizi ile değerlendirilmiştir. Anlamlılık düzeyi olarak 0,05 alınmış olup, $\mathrm{p}<0,05$ değeri istatistiksel olarak anlamlı kabul edilmiştir.

\section{BULGULAR}

Tablo 1'de hastaların genel özelliklerine göre dağılımı incelendiğinde, yaş ortalaması $76,3 \pm 10,1$ yıl olup, \%56,5'inin erkek, \%43,5'inin kadın olduğu, \%43,5'inin okuryazar olmadığı, \%35,5'inin de ilkokul mezunu olduğu bulunmuştur. Hastaların \%30,6'sının emekli, \%6,5'inin işçi, \%3,2'sinin memur, \%12,9'unun serbest meslek, \%41,9'unun ise ev hanımı olduğu saptanmıştır.

Çalışma kapsamına alınan kardiyovasküler hastalık tanılı bireylerin kardiyovasküler hastalık yanında, $\% 61,3$ 'ünde hipertansiyon, \%33,9'unda diyabet ve total kolesterol yüksekliği, \%14,5'inde kronik böbrek yetmezliği, $\% 12,9$ 'unda yüksek trigliseridemi, \%11,3'ünde eklemromatizmal hastalıkların da olduğu bulunmuştur. Anne baba ve kardeşlerin hastalık öyküsü incelendiğinde, sırasıyla kardiyovasküler hastalık $(\% 48,4)$, hipertansiyon $(\% 48,4)$, hiperkolesterolemi/hipertrigliseridemi $(\% 30,6)$ ve diyabet $(\% 30,6)$ görülmüsstür. Bununla birlikte ailesinde kalp krizi geçirme öyküsü bulunan birey sayısı da \%25,8 olarak bulunmuştur. Hastaların sadece \%14,6'sının düzenli olarak fiziksel aktivite (yürüyüş̧) yaptığı bulunmuştur. Sigara ve alkol kullanma durumları sorgulandığında ise \%6,5'inin sigara içtiği ve alkollü içecek tükettiği bulunmuştur. $\mathrm{Bu}$ çalışma kapsamına alınan bireylerin \%38,7'sinin ise daha önceden sigara içtiği ve bıraktığı saptanmıştır (Tablo 1).

Tablo 1. Bireylerin genel özelliklerine göre dağılımı

\begin{tabular}{|c|c|c|}
\hline & $\mathbf{n}$ & $\%$ \\
\hline \multicolumn{3}{|l|}{ Cinsiyet } \\
\hline Erkek & 35 & 56,5 \\
\hline Kadın & 27 & 43,5 \\
\hline \multicolumn{3}{|l|}{ Eğitim durumu } \\
\hline Okuryazar değil & 27 & 43,5 \\
\hline Okuryazar & 5 & 8,1 \\
\hline İlkokul mezunu & 22 & 35,5 \\
\hline Ortaokul-lise & 2 & 3,2 \\
\hline Yüksekokul-üniversite & 6 & 9,7 \\
\hline \multicolumn{3}{|l|}{ Meslek } \\
\hline İşçi & 4 & 6,5 \\
\hline Memur & 2 & 3,2 \\
\hline Serbest meslek & 8 & 12,9 \\
\hline Emekli & 19 & 30,6 \\
\hline Ev hanımı & 26 & 41,9 \\
\hline Diğer & 3 & 4,8 \\
\hline \multicolumn{3}{|c|}{ Aile hastalık öyküsü ve kalp krizi geçirme durumu } \\
\hline Kardiyovasküler hastalık & 30 & 48,4 \\
\hline Hipertansiyon & 30 & 48,4 \\
\hline Hiperkolesterolemi/hipertrigliseridemi & 19 & 30,6 \\
\hline Diyabet & 19 & 30,6 \\
\hline Kalp krizi & 16 & 25,8 \\
\hline \multicolumn{3}{|c|}{ Düzenli fiziksel aktivite yapma (haftada en az 3 gün 30 dk) } \\
\hline Evet & 9 & 14,6 \\
\hline \multicolumn{3}{|l|}{ Sigara kullanma durumu } \\
\hline Evet & 4 & 6,5 \\
\hline Hayır & 34 & 54,8 \\
\hline Biraktım & 24 & 38,7 \\
\hline \multicolumn{3}{|l|}{ Alkollü içecek tüketme durumu } \\
\hline Evet & 4 & 6,5 \\
\hline \multicolumn{3}{|c|}{$\begin{array}{l}\text { Bireylerin genel beslenme alışkanlıklarına göre } \\
\text { dağılımları tablo 2'de incelenmiştir. Tablo 2'ye göre bu } \\
\text { çalışmaya dahil edilen kardiyovasküler hastalık tanısı almış } \\
\text { bireylerin \%77,4'ünün beyaz ekmek tüketmeyi tercih ettiği, } \\
\% 17,7 \text { 'sinin yemekleri tuzlu tükettiği ve tadına bakmadan } \\
\text { tuz eklediği saptanmıştır. Ayrıca en sık kullanılan pişirme } \\
\text { yöntemleri arasında tencerede kendi suyuyla ağzı kapalı } \\
\text { olarak pişirme }(\% 88,7) \text {, yağda kızartma ve firında pişirme }\end{array}$} \\
\hline
\end{tabular}


$(\% 54,8)$ gelmektedir. En s1k tercih edilen yağ türü ise $\% 83,9)$ ile çiçek yağı, mısırözü yağı gibi bitkisel yağlardır. Daha sonra sirasiyla tereyağ $(\% 75,8)$ ve zeytinyağ $(\% 45,2)$ gelmektedir. Bireylerin yaklaşık yarısının $(\% 43,5)$ kırmızı eti yağlı tüketmeyi tercih ettiği, \%35,5'inin de kümes hayvanlarını derili olarak tükettiği saptanmıştır. Bireylerin günde $2,7 \pm 0,4$ ana öğün, $1,1 \pm 0,9$ ara öğün yaptığı, ortalama $6,4 \pm 3,2$ bardak su, $1,5 \pm 1,0$ porsiyon meyve, $1,5 \pm 0,6$ porsiyon da sebze tükettikleri bulunmuştur.

Tablo 2. Bireylerin genel beslenme alışkanlıklarına göre dağılımı

\begin{tabular}{|c|c|c|}
\hline & $\mathbf{n}$ & $\%$ \\
\hline \multicolumn{3}{|l|}{ Tüketilen ekmek türü } \\
\hline Beyaz & 48 & 77,4 \\
\hline Kepekli, çavdar, yulaflı & 14 & 22,6 \\
\hline \multicolumn{3}{|l|}{ Yemekteki tuz tercihi } \\
\hline Tuzlu & 11 & 17,7 \\
\hline Az tuzlu & 31 & 50 \\
\hline Tuzsuz & 20 & 32,3 \\
\hline \multicolumn{3}{|l|}{ Yemeklerin tadına bakmadan tuz ekleme durumu } \\
\hline Evet & 11 & 17,7 \\
\hline \multicolumn{3}{|l|}{ Yemek yeme hızı } \\
\hline Yavaş & 26 & 41,9 \\
\hline Orta & 26 & 41,9 \\
\hline Hizlı & 10 & 16,1 \\
\hline \multicolumn{3}{|l|}{ Yemek pişirme yöntemleri } \\
\hline Tencerede kendi suyuyla ağzı kapalı olarak pişirme & 55 & 88,7 \\
\hline Yağda kavurduktan sonra pişirme & 27 & 43,5 \\
\hline Yağda kızartma & 34 & 54,8 \\
\hline Fırında pişirme & 34 & 54,8 \\
\hline Izgara/mangal & 8 & 12,9 \\
\hline Haşlayıp suyunu dökme & 24 & 38,7 \\
\hline \multicolumn{3}{|l|}{ Yemeklerde en sık kullanılan yağ türü } \\
\hline Tereyăg & 47 & 75,8 \\
\hline Margarin & 3 & 4,8 \\
\hline Zeytinyağ & 28 & 45,2 \\
\hline Çiçekyağı, mısırözü vb. diğer yağlar & 52 & 83,9 \\
\hline \multicolumn{3}{|l|}{ Kırmızı eti tüketme durumu } \\
\hline Yağli etler & 27 & 43,5 \\
\hline Yağsız ve yarım yağlı etler & 35 & 56,5 \\
\hline \multicolumn{3}{|l|}{ Kümes hayvanları tüketme durumu } \\
\hline Derili & 22 & 35,5 \\
\hline Derisiz & 40 & 64,5 \\
\hline \multicolumn{3}{|l|}{ Süt ve süt ürünleri tüketme durumu } \\
\hline Tam yağlı & 57 & 91,9 \\
\hline Yarım yağl1 ve yağsız & 5 & 8,1 \\
\hline Market sütü & 25 & 40,3 \\
\hline Açıkta satılan süt & 37 & 59,7 \\
\hline Ana öğün sayısı/gün $\left(\mathrm{x}^{-} \pm \mathrm{SS}\right)$ & \multicolumn{2}{|c|}{$2,7 \pm 0,4$} \\
\hline Ara öğün sayısı /gün $\left(\mathrm{x}^{-} \pm \mathrm{SS}\right)$ & \multicolumn{2}{|c|}{$1,1 \pm 0,9$} \\
\hline Su tüketimi (bardak/gün) $(\overline{x \pm S S})$ & \multicolumn{2}{|c|}{$6,4 \pm 3,2$} \\
\hline Meyve tüketimi (porsiyon/gün) $\left(\mathrm{x}^{-} \pm \mathrm{SS}\right)$ & \multicolumn{2}{|c|}{$1,5 \pm 1,0$} \\
\hline Sebze tüketimi (porsiyon/gün) $\left(\bar{x}^{-} \pm \mathrm{SS}\right)$ & \multicolumn{2}{|c|}{$1,5 \pm 0,6$} \\
\hline
\end{tabular}

Bu çalışmada kardiyovasküler hastalık risk faktörlerinden olan HDL-kolesterol, LDL-kolesterol, trigliserit düzeyleri, bireylerin BKİ, bel ve kalça çevresi ile besin tüketim sıklıkları karşılaştırılmıştır. Kızartma, pirinç, makarna, erişte, kuruyemiş, kurubaklagil, sakatat, balık, kümes hayvanları, salam, sucuk, sosis gibi işlenmiş et ürünleri tüketim sıklığıyla bireylerin kardiyovasküler hastalık risk faktörleri arasında istatistiksel açıdan anlamlı bir ilişki bulunamamıştır ( $\mathrm{p}>0,05)$ (Tablo 3).

Ancak, besin tüketim sıklıklarıyla bireysel ölçümlerin karşılaştırılması sonucunda bireylerin fast food tüketim sıklığı ile LDL-kolesterol düzeyi arasında pozitif yönde anlamlı bir ilişki bulunmuştur $(r=0,260, p=0,041)$. Ayrıca kek, kurabiye, şekerleme gibi yiyeceklerin tüketim sıklığı arttıkça bireylerin LDL kolesterol değerlerinde de artış olduğu saptanmıştır $(r=0,252, p=0,048)$. Bununla birlikte hamur tatlıları tüketim sıklığının artmasına paralel olarak bireylerin LDL-kolesterol $(\mathrm{r}=0,253, \mathrm{p}=0,047)$ ve trigliserit düzeylerinin $(r=0,277, p=0,030)$ de $\operatorname{arttığ1~saptanmıştır.~}$ Benzer olarak, simit, poğaça, tost vb. tüketim sıklığıyla bireylerin trigliserit değerleri arasında da pozitif yönde anlamlı bir ilişki olduğu ortaya çıkarılmıştır $(r=0,338$, $\mathrm{p}=0,007$ ) (Tablo 3).

Bunun dışında süt ve süt ürünleri tüketim sıklığı arttıkça bireylerin HDL-kolesterol değerlerinin de arttığ1 görülmüştür ( $r=0,343, p=0,010)$. Benzer şekilde yumurta tüketim sıklığındaki artış $(r=0,262, p=0,039)$ ve çay/kahve tüketim sıklığındaki artış $(r=0,309, p=0,015)$ da HDLkolesterol düzeyini anlamlı ölçüde arttırmıştır. Bireylerin kırmızı et $(r=0,254, p=0,046)$ ile süt ve süt ürünlerinin tüketim sıklığıyla BKİ değerleri $(r=0,326, p=0,006)$ arasında pozitif yönde istatistiksel açıdan anlamlı bir ilişki bulunmuştur. Ayrıca patates haricindeki sebze ( $\mathrm{r}=-0,303$, $\mathrm{p}=0,017$ ) ve meyve tüketim sıklığ ile bireylerin bel çevresi $(r=-0,309, p=0,015)$ arasında negatif yönde anlamlı bir ilişki olduğu bulunmuştur. Buna göre bireylerin sebze ve meyve tüketim sıklıkları arttıkça bel çevresi değerleri azalmıştır (Tablo 3).

Bireylerin bel ve kalça çevresi ile beden kütle indeksi ölçümlerinin HDL-kolesterol, LDL-kolesterol ve trigliserit gibi bazı kardiyovasküler hastalık risk faktörleriyle karşılaştırılması sonucunda; hastaların bel çevresinin LDL kolesterol $(r=0,409$, $\mathrm{p}=0,001)$ ve trigliserid değeriyle $(\mathrm{r}=0,397, \mathrm{p}=0,001)$ pozitif yönde anlamlı olarak ilişkili olduğu bulunmuştur. Ayrıca hastaların bel/kalça çevresi oranının da LDL-kolesterol $(\mathrm{r}=0,401, \mathrm{p}=0,001)$ ve trigliserit düzeylerini $(\mathrm{r}=0,493, \mathrm{p}=0,000)$ pozitif yönde etkilediği bulunmuştur (Tablo 4). 
Tablo 3. Bireylerin bazı antropometrik ölçümlerinin ve kan bulgularının besin tüketim sıklıkları ile ilişkisi

\begin{tabular}{|c|c|c|c|c|c|c|c|}
\hline \multicolumn{8}{|c|}{$\begin{array}{cc}\text { Tüketim Sıklıkları } \\
\end{array}$} \\
\hline & Nadiren/Hiç & Ayda birkaç kez & Haftada 1-2 kez & Haftada 3-4 kez & Her gün & & \\
\hline & $\overline{\mathrm{x} \pm \mathrm{SS}}$ & $\overline{\mathrm{x} \pm \mathrm{SS}}$ & $\overline{\mathrm{x} \pm \mathrm{SS}}$ & $\overline{\mathrm{x} \pm \mathrm{SS}}$ & $\overline{\mathbf{x} \pm \mathrm{SS}}$ & $\mathbf{r}$ & $p$ \\
\hline \multicolumn{8}{|c|}{ Fast food tüketimi } \\
\hline LDL & $126,0 \pm 27,3$ & $147,2 \pm 26,1$ & $135,5 \pm 21,4$ & 135,0 & - & 0,260 & $0,041 *$ \\
\hline \multicolumn{8}{|c|}{ Kek, kurabiye, şekerleme vb. } \\
\hline LDL & $122,2 \pm 29,1$ & $138,6 \pm 19,0$ & $137,7 \pm 32,4$ & $142,0 \pm 20,3$ & - & 0,252 & $0,048 *$ \\
\hline \multicolumn{8}{|c|}{ Hamur tatlıları } \\
\hline LDL & $125,4 \pm 27,6$ & $124,8 \pm 27,4$ & $148,4 \pm 25,3$ & $137,7 \pm 8,7$ & - & 0,253 & $0,047 *$ \\
\hline TG & $151,3 \pm 68,3$ & $152,0 \pm 49,9$ & $187,1 \pm 56,4$ & $168,7 \pm 18,3$ & - & 0,277 & 0,030 * \\
\hline \multicolumn{8}{|l|}{ Yumurta } \\
\hline HDL & $43,0 \pm 7,0$ & $39,5 \pm 5,9$ & $35,8 \pm 6,4$ & $45,0 \pm 8,1$ & $46,5 \pm 13,9$ & 0,262 & $0,039 *$ \\
\hline \multicolumn{8}{|l|}{ Kırmızı et } \\
\hline BKİ & $29,0 \pm 6,2$ & $26,7 \pm 4,6$ & $27,4 \pm 4,4$ & $28,7 \pm 4,8$ & $35,0 \pm 7,7$ & 0,254 & $0,046 *$ \\
\hline \multicolumn{8}{|c|}{ Süt ve süt ürünleri } \\
\hline HDL & - & - & $35,8 \pm 7,7$ & $41,5 \pm 8,9$ & $45,9 \pm 10,9$ & 0,343 & $0,010 *$ \\
\hline BKİ & - & - & $26,3 \pm 3,8$ & $26,3 \pm 3,7$ & $30,8 \pm 5,5$ & 0,326 & $0,006 *$ \\
\hline \multicolumn{8}{|c|}{ Sebze (patates dıșındaki) } \\
\hline Bel çevresi & 130,0 & - & $106,2 \pm 11,4$ & $100,2 \pm 12,2$ & $95,7 \pm 13,9$ & $-0,303$ & $0,017 *$ \\
\hline \multicolumn{8}{|c|}{ Simit, poğaça, tost vb. } \\
\hline $\mathrm{TG}$ & $128,4 \pm 43,7$ & $189,6 \pm 64,8$ & $159,8 \pm 29,8$ & $136,0 \pm 22,6$ & - & 0,338 & $0,007 *$ \\
\hline \multicolumn{8}{|l|}{ Meyve } \\
\hline Bel çevresi & $100,7 \pm 14,0$ & $111,0 \pm 1,7$ & $108,9 \pm 12,0$ & $99,8 \pm 12,1$ & $96,4 \pm 13,9$ & $-0,309$ & $0,015^{*}$ \\
\hline \multicolumn{8}{|l|}{ Çay/kahve } \\
\hline HDL & 36,0 & 43,0 & $34,8 \pm 7,0$ & $38,2 \pm 3,3$ & $44,2 \pm 10,5$ & 0,309 & $0,015^{*}$ \\
\hline
\end{tabular}

Çalışmaya katılan bireylerin bel-kalça çevresi oranındaki artışın HDL kolesterol değerini düşürerek kardiyovasküler hastalık risk faktörleri üzerinde olumsuz bir etkisi olduğu görülmüştür ( $\mathrm{r}=-0,436, \mathrm{P}=0,000)$ (Tablo 4).

Tablo 4. Bireylerin bazı antropometrik ölçümleri ile kardiyovasküler hastalık risk faktörlerinin karşılaştırılması

\begin{tabular}{lllll}
\hline & Bel çevresi & Kalça çevresi & $\begin{array}{l}\text { B e } 1 / \text { k a lça } \\
\text { çevresi oran } 1\end{array}$ & BKI \\
\hline HDL kolesterol & $-0,239$ & 0,034 & $\mathbf{- 0 , 4 3 6}$ & 0,159 \\
& $\mathrm{p}=0,061$ & $\mathrm{p}=0,791$ & $\mathbf{p}=\mathbf{0 , 0 0 0 *}$ & $\mathrm{p}=0,218$ \\
LDL kolesterol & $\mathbf{0 , 4 0 9}$ & $\mathbf{0 , 2 5 4}$ & $\mathbf{0 , 4 0 1}$ & 0,108 \\
& $\mathbf{p}=\mathbf{0 , 0 0 1 *}$ & $\mathbf{p}=\mathbf{0 , 0 4 7 *}$ & $\mathbf{p}=\mathbf{0 , 0 0 1 *}$ & $\mathrm{p}=0,403$ \\
Trigliserid & $\mathbf{0 , 3 9 7}$ & 0,196 & $\mathbf{0 , 4 9 3}$ & 0,091 \\
& $\mathbf{p}=\mathbf{0 , 0 0 1 *}$ & $\mathrm{p}=0,127$ & $\mathbf{p}=\mathbf{0 , 0 0 0 *}$ & $\mathrm{p}=0,481$ \\
\hline
\end{tabular}

${ }^{*} \mathrm{p}<0,05$, Spearman korelasyon analizi kullanılmıştır.

\section{TARTIŞMA}

Çalışma kapsamına alınan kardiyovasküler hastalık tanısı almış bireylerin \%56,5'i erkek, \%43,5'i kadındır. Bireylerin \%43,5'i okuryazar değil, \%35,5'i ise ilkokul mezunu olup, yaş ortalaması 76,3 $\pm 10,1$ yıldır. Ailesinde kardiyovasküler hastalık ve hipertansiyon tanısı almış birey oran1 $\% 48,4$, hiperlipidemi ve diyabet $\% 30,6$ olup, ailesinde kalp krizi geçirme oranı ise \% 25,8 olarak bulunmuştur.

Bireylerin sadece \%14,6'sı düzenli olarak fiziksel aktivite yaptığını bildirmiştir. Düzenli olarak yapılan fiziksel aktivite vücut ağırlığını azaltır, LDL-kolesterol ve trigliserit düzeylerini düşürüp, HDL-kolesterol değerini ise arttırır. Kardiyovasküler hastalık riskini azaltmak için yapılan fiziksel aktivitenin türü, sıklığı ve süresi önemli olup, haftada en az 3-4 gün yarım saati aşacak şekilde hızlı yürüme, bisiklete binme, merdiven çıkma vb. aktiviteler yapılması önerilebilir (16).

Kardiyovasküler hastalıkların gelişiminde en önemli risk faktörlerinden biri de sigaradır. Yaptığımız bu çalışmada çalışmaya katılan bireylerin \%6,5'inin sigara ve alkol kullandığı, \%38,7'sinin ise daha önceden sigara içtiği ve bıraktığı saptanmıştır. Sigara içilmemesi, içiliyorsa bile bırakılması, fiziksel aktivitenin arttırılması, kan şekeri ve vücut ağırlığı kontrolü, sebze ve meyve tüketimini arttırmak gibi koruyucu faktörlerle birlikte kardiyovasküler hastalık riskini azaltmada önemli bir yere sahiptir (16). Alkol tüketimi ile kardiyovasküler hastalıklar arasında içecek türü ve içme şekline göre değişmekle birlikte J şeklinde bir ilişki olduğu bildirilmiştir. Buna göre hafif ila orta derecede (5 ila $25 \mathrm{~g}$ / 
gün, 1-2 kadeh/gün) alkol tüketimi kardiyovasküler hastalık gelişme riskiyle ve sonuçta ortaya çıkan ölüm oranlarının düşük olmasıyla ilişkiliyken, uzun süreli ve yüksek dozda alkol tüketimi ( $\geq 3$-4 kadeh/gün) kardiyovasküler hastalık gelişme riskini ve ölüm oranlarını arttırabilir (17).

Bu çalışmada bireylerin fast food tüketim sıklıklarının artmasının bir KVH risk göstergesi olan LDL-kolesterol değerini arttırdığı gösterilmiştir $(\mathrm{p}<0,05, \quad \mathrm{r}=0,260)$. Benzer şekilde İranlı yetişkinlerde fast food tüketiminin kardiyovasküler hastalık risk faktörleri üzerine etkisinin incelendiği 1944 yetişkin ve orta yaşlı bireyin katılımıyla gerçekleştirilen bir çalışmada; artmış fast food tüketiminin serum trigliserit, LDL-kolesterol ve aterojenik plazma indeks değerlerinde artış, HDL-kolesterol değerlerinde azalma gibi bazı KVH risk faktörleriyle ilişkili olduğu belirtilmiştir (18). Buna göre doymuş yağ, sodyum ve kolesterol yönünden zengin, posa ve mikro besin öğelerince fakir olan fast food tüketiminin $\mathrm{KVH}$ risk faktörleri üzerinde olumsuz yönde etkili olabileceği ve tüketiminin sınırlandırılmasının uygun olabileceği söylenebilir.

Çalışma kapsamına alınan bireylerin süt ve süt ürünleri tüketim sıklığındaki artışın HDL-kolesterolü pozitif yönde anlamlı olarak arttırdığı, bununla birlikte BKI'deki artışla da paralel olarak ilişkili olduğu saptanmıştır. Benzer şekilde Sun ve ark. (19), 50 yaş üstü Çinli bireyler üzerinde yaptıkları geniş kapsamlı bir çalışmada süt tüketiminin trigliseritlerle negatif yönde, HDL kolesterolle pozitif yönde anlamlı olarak ilişkili olduğunu göstermişlerdir. Ayrıca erkeklerde süt tüketimindeki artışın BKI'yle anlamlı olarak ilişkili olmadığı bulunmasına karşın, kadınlarda süt tüketiminin BKİ ile pozitif yönde anlamlı olarak ilişkili olduğu bulunmuştur. Tucker ve ark. (20), yüksek düzeyde süt ve süt ürünleri tüketen ( $2,4 \pm 0,9$ porsiyon/gün) bireylerin 1lımlı $(1,0 \pm 0,4$ porsiyon/gün) ve düşük düzeyde $(0,2 \pm 0,2$ porsiyon/gün) tüketenlere göre vücut ağırlıkları ve vücut yağ yüzdeleri arasında anlamlı bir fark bulamamıştır. Süt ve süt ürünleri tüketimiyle BKİ arasındaki ilişki üzerine yapılan çalışmalar tutarsız sonuçlar vermektedir. $\mathrm{Bu}$ nedenle süt ve süt ürünleri tüketiminin BKİyle pozitif yönde ilişkili olduğunu veya kilo kaybetmeye yardımcı olduğunu söylemek mümkün değildir. Sonuç olarak dengeli bir diyette süt ve süt ürünleri tüketiminin kardiyovasküler hastalık risk faktörlerini olumlu yönde etkileyebileceği düşünülmektedir.

$\mathrm{Bu}$ çalı̧̧mada bireylerin \%43,5'i kırmızı et tercihinin yağlı etlerden yana olduğunu belirtirken, \%35,5'i kümes hayvanlarını derili, \%91,9'u süt ve süt ürünlerini tam yağlı tüketmeyi tercih etmektedir. Ayrıca yemeklerde çiçek yağı, mısırözü yağı gibi yağlardan sonra $(\% 83,9)$ en çok kullanılan yağ türü tereyağıdır $(\% 75,8)$. Yemek pişirme yöntemlerinin kullanılma durumuna bakıldığında ise hastaların yarıdan fazlasının $(\% 54,8)$ yağda kızartma yöntemini $\% 43,5$ 'inin de yağda kavurduktan sonra pişirme yöntemini tercih ettiği görülmüştür. Postmenepozal kadınlarda tekli doymamış yağlardan zengin (sızma zeytinyağı) bir diyetle doymuş yağlardan zengin (tereyağ) bir diyetin antropometrik, metabolik ve lipit profili üzerine etkisini inceleyen bir çalışmada; doymuş yağlardan zengin bir diyetin kardiyovasküler riski arttırırken, tekli doymamış yağlardan zengin bir diyetin kardiyovasküler hastalık gelişme riskini azalttığı saptanmıştır (21). 1875 yaşları arasında olan ve ortalama 6,6 yıl boyunca takip edilen 11,116 katılımcıdan oluşan bir kohort çalışmasında hayvansal proteinlerce zenginleştirilmiş bir diyetin, özellikle sigara içenler arasında kardiyovasküler hastalık nedeniyle olan ölüm riskini arttırabileceği sonucuna varılmıştır (22). Amerikan Kalp Cemiyeti, kardiyovasküler hastalıklarla ilgili olarak, yağsız et tüketiminin yağlı et tüketimine tercih edilmesi gerektiğini, doymuş yağlardan zengin işlenmiş et tüketiminin sınırlandırılması gerektiğini ve et tercihinin ızgarada ya da firında olması gerektiğini bildirmiştir (23).

$\mathrm{Bu}$ çalışmada her gün kırmızı et tüketen bireylerin BKI'leri $(35,0 \pm 7,7)$ daha az siklıkla $(28,7 \pm 4,8,27,4 \pm 4,4$, $26,7 \pm 4,6,29,0 \pm 6,2)$ kırmızı et tüketen bireylere göre daha yüksek bulunmuş olup, kırmızı et tüketim sıklığı BKİ ile pozitif yönde ilişkili bulunmuştur $(r=0,254, p=0,046)$. Benzer şekilde 18 çalışmanın ele alındığı bir metaanaliz çalışmasında daha fazla kırmızı et ve işlenmiş et tüketiminin daha yüksek BKİ ve bel çevresiyle ilişkili olduğu ve obezite riskini 1,32 kat arttırdığ 1 bulunmuştur $(p=0,001)$ (24). Sonuç olarak genel popülasyonda kırmızı et tüketimindeki sağlanacak azalma obezite üzerinde olumlu bir etkiye, dolayısıyla kardiyovasküler hastalık riskini ve mortalite oranlarını azaltıcı bir etkiye sahip olabileceği düşünülmektedir.

$\mathrm{Bu}$ çalışmada hamur tatlıları, kek, kurabiye, şekerleme vb. tüketim sıklığındaki artış bireylerin LDL-kolesterol değerleriyle pozitif yönde anlamlı bir ilişki göstermiştir. Benzer olarak yapılan bir çalışmada şeker içeriği yüksek bir diyetin total kolesterol, LDL-kolesterol ve trigliserit düzeylerini arttırdığ 1 bulunmuştur (25). Yüksek şeker ve rafine karbonhidrat içeren diyetler, artmış kan şekeri, insülin düzeyi, bozulmuş glikoz toleransı gibi kardiyovasküler riskle ilişkili birçok anormalliği tetikleyebilir (26). Eklenmiş şeker 
yönünden zengin bir diyetin kardiyovasküler hastalıklardan ölüm oranını 3 kat arttırdığı bulunmuştur (26). Bu sonuca göre kardiyovasküler hastalıklarda basit karbonhidrat tüketimi kardiyovasküler hastalık risk faktörlerini arttırmamak ve hastalığın prognozunu kötüleştirmemek için sinırlandırılabilir.

Yumurta tüketim sıklığına paralel olarak bireylerin HDL-kolesterol değerleri de artmıştır $(r=0,262, p=0,039)$. Yapılan çalışmalar yumurta tüketiminin HDL-kolesterolü arttırdığını ve HDL partikül profillerini geliştirdiğini bulmuştur $(27,28)$. HDL-kolesterol, arterden fazla lipidi çıkararak ve vücuttan karaciğere geri aktararak lipitleri atması sayesinde kardiyovasküler hastalıkları iyileştirir (29). Yumurta diyetteki en zengin kolesterol kaynaklarından biridir. Ancak, yumurta fosfolipitler, antioksidan karotenoidler (lutein ve zeaksantin) gibi kardiyovasküler hastalık riskini azaltacak diğer faktörlere sahip olması nedeniyle kardiyovasküler hastalıklara karşı koruyucudur (29). HDL-kolesterol üzerinde olumlu etkileri nedeniyle kardiyovasküler hastalıklarda haftada 1-2 kez yumurta tüketilmesi tavsiye edilebilir (14).

$\mathrm{Bu}$ çalışmada çay, kahve tüketim sıklığındaki artışın bireylerin HDL kolesterol değerinde anlamlı bir artış sağladığı saptanmıştır. Benzer şekilde Grosso ve ark. (30), yüksek kahve/çay (günde 3 veya daha fazla bardak) ve düşük kahve/çay (günde 1 bardaktan daha az ) tüketen bireylerde yaptıkları bir çalışmada; çay ve kahveyi yüksek tüketen bireylerin düşük tüketenlere göre daha yüksek HDL kolesterol seviyelerine sahip oldukları bulunmuştur. Kronik hastalıklarla negatif ilişkili olduğu öne sürülen çay ve kahve tüketiminin yüksek vitamin ve polifenol içerikleri sayesinde kardiyovasküler hastalıklar üzerinde de faydalı olduğu ve bu nedenle de kardiyovasküler hastalıklarda tüketiminin tavsiye edilebileceği söylenebilir.

Bizim çalışmamızda bireylerin LDL-kolesterol düzeyleri ve trigliserit düzeyleri ile bel çevresi arasında pozitif yönde anlamlı bir ilişki bulunmuştur. Ayrıca bel-kalça oranı da HDL-kolesterolle negatif yönde, LDL-kolesterol ve trigliserit düzeyleri ile pozitif yönde anlamlı olarak ilişkilidir. Benzer şekilde Oboh ve ark. (31), bel çevresi, belkalça oranı gibi antropometrik ölçümlerin bireylerin serum lipit alt gruplarındaki artışla pozitif yönde ilişkili olduğunu göstermişlerdir. Chitra ve ark. (32) da diyet, egzersiz ve serum lipit profilleri arasındaki ilişkiyi inceledikleri bir çalışmada; bel çevresi ile hem total kolesterol hem de LDL-kolesterol arasında pozitif yönde anlamlı bir ilişki bulmuşlardır. Ayrıca bel çevresinin de serum trigliseridleri ile pozitif yönde ilişkili olduğu belirtilmiştir. Kilo kaybı miktarının toplam kolesterol, HDL-kolesterol, LDLkolesterol ve sistolik kan basıncı düzeyi gibi kardiyovasküler risk faktörleri üzerinde olumlu yönde etkileri olduğu gösterilmiştir (33). Obezitenin kardiyovasküler hastalık için bağımsız bir risk faktörü olduğu kanıtlanmış bir gerçektir. Vücut ağırlığı, beden kütle indeksi, bel çevresi ve bel-kalça oranı, vücut yağının öncelikle karın bölgesinde toplandığı android tip obezite ile ilişkilidir (34). Bel çevresi değerinin kadınlarda $80 \mathrm{~cm}$, erkeklerde $94 \mathrm{~cm}$ 'in altında olması, bel/ kalça oranının ise kadınlarda $0,85^{\prime}$ 'in, erkeklerde 0,90 'ın altı olması hastalık risklerini azaltır (14). Yapılan çalışmalar android tip obezitenin genel obeziteye göre kardiyovasküler hastalık riskinde daha anlamlı sonuçlar ortaya koyduğunu göstermiştir $(35,36)$. Buna göre kardiyovasküler hastalık riskini ve mortalite oranlarını azaltmak için obezitenin, özellikle android tip obezitenin önüne geçilmeli ve bunun için yine sağlıklı bir beslenme şekli benimsenmelidir.

$\mathrm{Bu}$ çalışmada bireylerin günde $1,5 \pm 1,0$ porsiyon meyve, 1,5 $\pm 0,6$ porsiyon da sebze tükettikleri bulunmuştur. Ayrıca sebze ve meyve tüketimi ile android tip obezite ve kardiyovasküler hastalık risk göstergelerinden biri olan bel çevresi ölçümü arasında negatif yönde anlamlı bir ilişki bulunmuştur. Sebze ve meyve yönünden zengin bir beslenme şekli (günde en az 5 porsiyon) hem obezite hem de kardiyovasküler hastalıklardan koruyucu ve hastalığın yönetiminde olumlu yönde etkili olabileceği için tüketiminin arttırılması önerilebilir.

\section{SONUÇ VE ÖNERILER}

Kardiyovasküler hastalık tanısı almış bireyler arasında düzenli olarak fiziksel aktivite yapma oranı oldukça düşük bulunmuş olup, özellikle kardiyovasküler hastalıklardan korunmak veya ölüm oranlarını azaltmak için düzenli olarak fiziksel aktivite yapılması önerilebilir.

Kalp sağlığını koruyucu bir diyet modeli tüketmek, daha iyi antropometrik ölçümler, kan basıncı ve kan lipitleri düzeyini sağlayacağı için teşvik edilmelidir. Hastalara yaşam tarzı ve beslenme alışkanlıklarını daha sağlıklı hale getirmeleri gerektiği anlatılmalıdır. Sağlıklı beslenmeye yönelik eğitimler yapılmalı hastaların çoğu yaşlı olduğu için bu konuda ailelerden de destek alınmalıdır. Optimal kardiyovasküler sağlık için kişiye özel etkili diyetler planlanmalıdır. Doymuş yağ ve doymuş yağ içeren besinlerin alımı kısıtlanmalı ancak, doymuş yağların yerini basit karbonhidratların alması engellenmelidir. Bireylerin 
özellikle bel çevresi ve bel/kalça oranı gibi antropometrik ölçümlerin kardiyovasküler hastalık risk göstergelerinden biri olan obeziteyle ilişkili olduğu ve HDL-kolesterol, LDL-kolesterol ve trigliserit gibi kan bulgularını etkilediği bulunmuş olup, antropometrik ölçümlerin normal sınırlar içinde tutulmasına özen gösterilmelidir. Dolayısıyla kardiyovasküler hastalık tanısı almış bireyler arasında HDL kolesterolü istenen düzeylere $(40-60 \mathrm{mg} / \mathrm{dl})$ çıkarmak için çay/kahve, yumurta, süt ve süt ürünleri tüketimi arttırılmalı, hastaların LDL kolesterol ve trigliserit düzeylerini yükseltmemek adına fast food, eklenmiş şeker içeren besinler, hamur işleri ve yağlı et tüketimi azaltılmalıdır. Tam tahıllar, beyaz et, az yağlı süt ve süt ürünleri, çay, kahve (günde 3-5 fincan veya $400 \mathrm{mg} /$ gün), salata ve sebze yemekleri (günlük en az $400 \mathrm{~g}$ (5 porsiyon) taze sebze ve meyve) ve zeytinyağından zengin bir beslenme tarzı tercih edilmelidir. Ayrıca kardiyovasküler hastalık risk göstergelerinden biri olan bel/kalça oranını düşürmek için fiziksel olarak aktif olmanın yanında, sağlıklı bir beslenme şekli benimsenmelidir.

Sonuç olarak beslenme modifikasyonlarının kardiyovasküler hastalıkları önlemede ele alınması gerektiği açıktır. Diyette ve yaşam şeklinde yapılan bazı değişiklikler, kardiyovasküler hastalık risk faktörleri üzerinde olumlu değişiklikler ortaya çıkaracaktır. Çalışmanın daha büyük örneklemlerle tekrarlanması önerilmektedir.

\section{KAYNAKLAR}

1. Pawlak, R. Is Vitamin B12 Deficiency a Risk Factor for Cardiovascular Disease in Vegetarians? American Journal of Preventive Medicine, 2015;48 (6): e11-e26.

2. Ünal, B. Ergör, G. Türkiye Kronik Hastalıklar ve Risk Faktörleri Sıklığı Çalışması (TKrHRF). Türkiye Cumhuriyeti Sağlık Bakanlığı, Ankara, 2013.

3. Jokinen E. Obesity and cardiovascular disease. Minerva pediatrica. 2015;67(1):25-32.

4. Kranendonk MEG, de Kleijn DPV, Kalkhoven E, Kanhai DA, Uiterwaal CSPM, van der Graaf Y, et al. Extracellular vesicle markers in relation to obesity and metabolic complications in patients with manifest cardiovascular disease. Cardiovascular diabetology. 2014;13:37.

5. Jiang J, Ahn J, Huang WY, Hayes RB. Association of obesity with cardiovascular disease mortality in the PLCO trial. Preventive medicine. 2013;57(1):60-64.

6. Mertens E, Markey O, Geleijnse JM, Givens DI, Lovegrove JA. Dietary Patterns in Relation to Cardiovascular Disease Incidence and Risk Markers in a Middle-Aged British Male Population: Data from the Caerphilly Prospective Study. Nutrients. 2017;9(1):75.
7. Mohammadifard N, Talaei M, Sadeghi M, Oveisegharan S, Golshahi J, Esmaillzadeh A, et al. Dietary patterns and mortality from cardiovascular disease: Isfahan Cohort Study. European Journal Of Clinical Nutrition. 2016;71:252.

8. Nanri A, Mizoue T, Shimazu T, Ishihara J, Takachi R, Noda $\mathrm{M}$, et al. Dietary patterns and all-cause, cancer, and cardiovascular disease mortality in Japanese men and women: The Japan public health center-based prospective study. PloS one. 2017;12(4):e0174848.

9. Siri-Tarino PW, Krauss RM. Diet, lipids, and cardiovascular disease. Current opinion in lipidology. 2016;27(4):323-328.

10. Mirmiran P, Bahadoran Z, Vakili AZ, Azizi F. Western dietary pattern increases risk of cardiovascular disease in Iranian adults: a prospective population-based study. Applied physiology, nutrition, and metabolism $=$ Physiologie appliquee, nutrition et metabolisme. 2017;42(3):326-332.

11. Stamatelopoulos K, Papavagelis C, Augoulea A, Armeni E, Karagkouni I, Avgeraki E, et al. Dietary patterns and cardiovascular risk in postmenopausal women: Protocol of a cross-sectional and prospective study. Maturitas. 2018;116:59-65.

12. Tourlouki E, Matalas AL, Panagiotakos DB. Dietary habits and cardiovascular disease risk in middle-aged and elderly populations: a review of evidence. Clinical interventions in aging. 2009;4:319-330.

13. Sikand G, Kris-Etherton P, Boulos NM. Impact of functional foods on prevention of cardiovascular disease and diabetes. Current cardiology reports. 2015;17(6):39.

14. Türkiye Beslenme Rehberi, TÜBER. 2015. T.C. Sağl1k Bakanlığı Yayın No:1031, Ankara 2016.

15. Pekcan G. Beslenme durumunun saptanmasi. Diyet El Kitabi Hatipoglu Yayinevi Ankara. 2008:67-141.

16. Yeşil P, Altıok M. Kardiyovasküler hastalıkların önlenmesi ve kontrolünde fiziksel aktivitenin önemi. Türk Kardiyoloji Derneği Kardiyovasküler Hemşirelik Dergisi. 2012;3:39-48.

17. Mostofsky E, Chahal HS, Mukamal KJ, Rimm EB, Mittleman MA. Alcohol and Immediate Risk of Cardiovascular Events: A Systematic Review and Dose-Response Meta-Analysis. Circulation. 2016;133(10):979-987.

18. Bahadoran Z, Mirmiran P, Golzarand M, Hosseini-Esfahani F, Azizi F. Fast food consumption in Iranian adults; dietary intake and cardiovascular risk factors: Tehran Lipid and Glucose Study. Archives of Iranian medicine. 2012;15(6):346-351.

19. Sun Y, Jiang C, Cheng KK, Zhang W, Leung GM, Lam TH, et al. Milk consumption and cardiovascular risk factors in older Chinese: the Guangzhou Biobank Cohort Study. PloS one. 2014;9(1):e84813.

20. Tucker LA, Erickson A, LeCheminant JD, Bailey BW. Dairy consumption and insulin resistance: the role of body fat, physical activity, and energy intake. Journal of diabetes research. 2015;2015:206959.

21. Anderson-Vasquez HE, Perez-Martinez P, Ortega Fernandez $\mathrm{P}$, Wanden-Berghe C. Impact of the consumption of a rich diet in butter and it replacement for a rich diet in extra virgin olive oil on anthropometric, metabolic and lipid 
profile in postmenopausal women. Nutricion hospitalaria. 2015;31(6):2561-2570.

22. Chen Y, McClintock TR, Segers S, Parvez F, Islam T, Ahmed A, et al. Prospective investigation of major dietary patterns and risk of cardiovascular mortality in Bangladesh. International journal of cardiology. 2013;167(4):1495-1501.

23. Lichtenstein AH, Appel LJ, Brands M, Carnethon M, Daniels $\mathrm{S}$, Franch HA, et al. Diet and lifestyle recommendations revision 2006: a scientific statement from the American Heart Association Nutrition Committee. Circulation. 2006;114(1):82-96.

24. Rouhani MH, Salehi-Abargouei A, Surkan PJ, Azadbakht L. Is there a relationship between red or processed meat intake and obesity? A systematic review and meta-analysis of observational studies. Obesity Reviews. 2014;15(9):740748 .

25. Te Morenga LA, Howatson AJ, Jones RM, Mann J. Dietary sugars and cardiometabolic risk: systematic review and metaanalyses of randomized controlled trials of the effects on blood pressure and lipids. Am J Clin Nutr. 2014;100(1):6579.

26. DiNicolantonio JJ, Lucan SC, O'Keefe JH. The Evidence for Saturated Fat and for Sugar Related to Coronary Heart Disease. Progress in cardiovascular diseases. 2016;58(5):464472 .

27. Blesso CN, Andersen CJ, Bolling BW, Fernandez ML. Egg intake improves carotenoid status by increasing plasma HDL cholesterol in adults with metabolic syndrome. Food \& function. 2013;4(2):213-221.

28. Mutungi G, Waters D, Ratliff J, Puglisi M, Clark RM, Volek JS, et al. Eggs distinctly modulate plasma carotenoid and lipoprotein subclasses in adult men following a carbohydrate-restricted diet. The Journal of nutritional biochemistry. 2010;21(4):261-267.

29. Blesso CN. Egg phospholipids and cardiovascular health. Nutrients. 2015;7(4):2731-2747.

30. Grosso G, Stepaniak U, Micek A, Topor-Madry R, Pikhart $\mathrm{H}$, Szafraniec K, et al. Association of daily coffee and tea consumption and metabolic syndrome: results from the Polish arm of the HAPIEE study. European journal of nutrition. 2015;54(7):1129-1137.

31. Oboh HA, Adedeji AA. Correlation of waist-hip-ratio and waist-height-ratio to cardiovascular risks factors in a Nigerian population. Nigerian quarterly journal of hospital medicine. 2011;21(1):16-24.

32. Chitra U, Reddy NK, Balakrishna N. Role of lifestyle variables on the lipid profile of selected South Indian subjects. Indian heart journal. 2012;64(1):28-34.

33. Milsom VA, Malcolm RJ, Johnson GC, Pechon SM, Gray $\mathrm{KM}$, Miller-Kovach K, et al. Changes in cardiovascular risk factors with participation in a 12-week weight loss trial using a commercial format. Eating Behaviors. 2014;15(1):68-71.

34. Kinoshita M, Yokote $\mathrm{K}$, Arai H, Iida M, Ishigaki Y, Ishibashi S, et al. Japan Atherosclerosis Society (JAS) Guidelines for Prevention of Atherosclerotic Cardiovascular Diseases 2017. Journal of atherosclerosis and thrombosis. 2018;25(9):846984.

35. Goh LGH, Dhaliwal SS, Welborn TA, Lee AH, Della PR. Anthropometric measurements of general and central obesity and the prediction of cardiovascular disease risk in women: a cross-sectional study. BMJ open. 2014;4(2):e004138.

36. Fan H, Li X, Zheng L, Chen X, Lan Q, Wu H, et al. Abdominal obesity is strongly associated with Cardiovascular Disease and its Risk Factors in Elderly and very Elderly Communitydwelling Chinese. Scientific reports. 2016;6:21521. 